\title{
NEW VARIANT OF THE FIRM: A MARKET-LIKE FORM
}

\author{
Judit Kapás \\ Department of Economics University of Debrecen 4028 Debrecen, Kassai str. 26, Hungary \\ tel.: $+36-52-416-580$, fax.: $+36-52-419-728$ \\ e-mail: judit.kapas@econ.unideb.hu
}

Received 30 November 2004; accepted 10 December 2004

\begin{abstract}
The paper is concerned with the issue of variants within a firm, the causes of their emergence and coexistence. A particular attention is paid to the New Economy's variant called market-like form. It is contrasted with the M-form firm that was dominated over the last century. Significant shift in physical technology is thought to be a major force driving the evolution process of a firm which is characterized by the emergence of new variants. The paper also analyzes how the character of the production technology determines which variant of the firm is the best suitable to a particular technology.
\end{abstract}

Keywords: theory of the firm, M-form, social technology, New Economy

JEL Code: D20, L22, O30

\section{Introduction}

The theory of the firm is only a 30 years old branch of economics which is originated from the work of Oliver Williamson in the early 70s. Quite naturally it is evolving and, as opposed to the original Grand Questions $^{1}$ to be answered by the theory, it must provide an explanation for new issues as well. Among such issues, below, I will explore the question of the evolution of the firm, more specifically that of the variants within a firm. This issue, I think, is of importance both for theoretical and empirical reasons.

The empirical one relates to an existing phenomenon in the New Economy, i.e., the emergence and the preponderance of a new variant of a firm that I call a market-like form. This organizational type involves such coordination mechanisms that were thought before to be the characteristics only of a market. As far as the theory of the firm is concerned, the problem is not only that the dominant transaction cost economics is unable to explain the reasons of this variety, but, which is a more severe problem; it does not strive to deal with such an issue. However, in my view, the theory of the firm must keep pace with real phenomena; as a consequence it must provide an explanation for the coexistence of variants within a firm. ${ }^{2}$ I will also show below that the question of variants cannot be simply reduced to that of the internal organization of the firm which is, indeed, one of the Grand Questions; instead, it concerns an issue, namely the evolution of the firm which is not taken seriously in the transaction cost economics.

In this paper I am concerned with analyzing alternative forms within a firm, rather than with analyzing

1 It is widely accepted that the theory of the firm is concerned with the questions of (1) the existence, (2) the boundary and (3) the internal organization of the firm.

2 Foss (2001) seems to be in accordance with my view. The author puts forward three reasons why an understanding of a market-like form is an important challenge: (1) It concerns important and real phenomenon. (2) It pushes us to rethink some "classic" issues in the theory of the firm. (3) Existing approaches, such as transaction cost economics, are not capable of providing an adequate explanation for this. 
markets and firms. But I think many of the same principles apply. My argument is that the firm exists in numerous variants ${ }^{3}$, of which Williamson (1975, 1985) has identified two, namely the $U$ and the Mform. Williamson's theory should have been seen as a reflection of its time, but times have changed, and a new variant of the firm has emerged. What is the reason for this? Or more generally, why are there numerous variants within a firm? How the new variant can be contrasted with the multidivisional form that has dominated over a decade, but it does not dominate today. What determine which variant of the firm is in preponderance? In this piece I try to provide answers to these questions.

The paper is organized as follows. In section 2 I present the theoretical background, i.e., the Williamsonian theory of governance structures. In section 3 and 4, respectively, I discuss the $U$ and the M-form in a way Williamson has treated them, and I draw some conclusions that serve as starting points for further discussion. In section 5 I sketch out the major attributes of a market-like form and contrast it with the M-form. Here I will also discuss the driving force behind the emergence of new variants within a firm. The issue of what is common in all variants of the firm, i.e., what the distinctive mark of the firm is will be addressed in Section 6. Section 7 deals with the issue of the coexistence of variants and the last section draws some conclusions.

\section{The Williamsonian theory of governance structures}

Williamson's (1985) theory of governance structures is widely accepted as a framework for a classification of the organizational forms and this serves as a main guideline in the understanding of why different institutions emerge for coordinating transactions. Williamson distinguishes three types of governance structures, namely market, firm and hybrid form ${ }^{4}$. All these forms may have transaction cost advantage over the others depending on the characteristics of a transaction. He identifies three dimensions of transactions which he contends dictate whether markets, hybrids or firms are more efficient: uncertainty, asset specificity, frequency. This tricho- tomous view was further elaborated in Williamson (1991). Here he discusses the key attributes with respect to which governance structures differ. Thus, he indicates three criteria for stressing the differences between the forms. These are as follows: (1) contract law, (2) performance attributes, and (3) instruments.

Williamson puts forth that each generic form of governance - market, firm, and hybrid - needs to be supported by a different form of contract law. According to him, there is a one-to-one correspondence between them, i.e., classical law applies to "thick" markets, neo-classical contract law is ideal for hybrid forms, and the (implicit) contract law that supports firms is that of forbearance.

Besides the type of contract law, there are crucial differences in adaptability. The issue of adaptability refers to the economic problem identified by Hayek (1945:254): ,the economic problem of society is mainly one of rapid adaptation in the particular circumstances of time and place". Hayek argues that the price system (market) has enormous advantage over central planning for inducing change. In other words, Hayek speaks of an adaptive capacity in the market. On the contrary, Barnard (1938) - who also holds that the main problem of organization was that of adaptation - locates adaptive capacity within organization. Williamson argues that both scholars are correct, but, they refer to different kinds of adaptation that are needed for a high performance. The adaptation that takes place within the firm is referred to as cooperation (adaptation (C)), the adaptation assured in markets is called autonomous adaptation (adaptation (A)).

The third distinguishing attribute refers to the type of incentive and control instruments used in a given governance form. In markets high-powered incentives are used (Williamson 1988), while internal organization degrades incentive intensity. Besides this, administrative controls develop in the opposite way: hierarchy is infused with an intensive use of administrative instruments. Table 1 summarizes the distinguishing attributes of market, firm, and hybrid.

As it is shown in the table, markets and hierarchies (firms) are polar opposites, and hybrids are in-between displaying intermediate values in all five features: "the

\footnotetext{
The concept of a variant is borrowed from an evolutionary theory which proposes that the system in question is subject to somewhat random variation within which some kinds of mechanism selects and also that there are inertial forces that provide continuity of what survives (Nelson 1995). In this spirit, variants of a firm are representatives of the same governance structure (organizational form), namely the firm, exhibiting to some extent different characteristics while retaining the same distinctive one which guarantees that they are of the same nature.

4 Hybrid forms are various forms of long-term contracting between autonomous firms, such as licensing, franchising, supplier chains, strategic alliances, etc.
} 
Table 1. Distinguishing Attributes of Market, Hybrid, and Hierarchy Governance Structures

(Williamson 1991, p. 281.)

\begin{tabular}{|l|c|c|c|}
\hline & \multicolumn{2}{|c|}{ Governance Structure } \\
\hline Attributes & Market & Hybrid & Hierarchy \\
\hline Instruments & & & 0 \\
\hline Incentive intensity & ++ & + & ++ \\
\hline Administrative control & 0 & & 0 \\
\hline Performance attributes & & + & ++ \\
\hline Adaptation (A) & ++ & + & 0 \\
\hline Adaptation (C) & 0 & + & + \\
\hline Contract law & ++ & & + \\
\hline
\end{tabular}

$++=$ strong, $+=$ semi-strong, $0=$ weak

hybrid mode is characterized with semi-strong incentives, an intermediate degree of administrative controls, displays semi-strong adaptations of both kinds, and works out a semi-legalistic contract law regime" (Willliamson 1991:281).

This scheme is very simple, however, particularly useful to understand what the major differences between the modes of coordination are. Nevertheless, note that while Williamson (1991:280) himself talks about the variety as regards hybrid forms, he is not so clear on the same topic as regards market and hierarchy. 5

What is of great importance for my concern is that hierarchy is presented in the Williamsonian framework of governance structures as being rather homogenous. At the same time, in a different story, Willliamson (1975:133-154) talks about different firm organizational types, namely the U-form and the Mform. When analyzing these forms he implicitly treats these as variants within a hierarchy, exhibiting to a certain degree different attributes. My argument is that Williamson's representation of the $\mathrm{U}$ and $\mathrm{M}$-forms is in tension with his theory of governance structures: the characteristics of a firm as shown in Table 1 cannot be conciliated with the $\mathrm{U}$ and M-forms' description. The tension consists in that that Williamson, in his theory of governance structures, differentiates as regards the attributes' level of intensity (see first column in Table 1) only among governance structures, but, in his theory of the Mform, since he shows it as combining the advantages of hierarchies and markets, it would be necessary to differentiate within a firm as governance structure as well. I will argue that the concept of social technology (Nelson 2002) is a useful tool, on the one hand, to resolve this "among versus within" tension, and on the other hand, to understand why variants within a firm have emerged and continue to emerge. This argument will be developed below. Let me start by describing variants within the firm, respectively the $U$, the $M$ and the market-like form.

\section{The U-form and the M-form as described by Williamson}

The traditional large, single-product business firm emerged in the late 1880s in steel, tobacco, oil, and so forth, and was organized into functional departments such as sales, finance, production, engineering, etc, with the corporate office actively coordinating the activities of functional departments; daily interventions were at regular basis. Williamson (1964) refers to this firm as being of a unitary or Uform organizational type. A major characteristic of the U-form is that the contribution of each department to corporate profit is neither directly observable nor measurable. As a result, Williamson argues, firm resources would be allocated to different functional departments according to a bargaining power of departmental heads. Since the heads' status derives from the size and importance of their department, growth is the major goal of the U-form. This implies certain degree of managerial slack.

As argued by Williamson (1975:132-135), the U-form eventually may run into control loss and strategy formulation problems when expanding in size and diversity. These are consequences, according to him, of bounded rationality and opportunism. As far as the first problem is concerned, centralization of decisions creates high coordination costs. As regards the second one, short run urgent operating crises may push

5 The fact that hybrids can exist in many various forms stems directly from the fact that hybrids exhibit intermediate values in all characteristics, i.e., they combine the features of markets and firms. This combination, of course, can be of numerous type. For a detailed overview of the types of hybrids see Ménard (2004). 
strategic decision making at lower level causing profit distortion. All these severe efficiency problems accompany the growth of the U-form, but, could be mitigated by the M-form.

The historical development of the $\mathrm{M}$-form ${ }^{6}$ is described in Chandler's seminal work (Chandler 1962); this is why it is also referred to as Chandlerian firm. Chandler explored what occurred when some American large firms that were organized on a functional basis began to pursue the strategy of diversification in the 1920s: functional departments found themselves having to deal with several businesses, which led to coordination problems and top officers were not able to identify the profit contribution of each business, which contributed to a suboptimal allocation of financial resources. As Langlois (2003a, 2003b) argues, with the lowering of transportation and communication cost there arose profit opportunities for those firms who could create mass markets and take advantage of economies of scale. According to Chandler, the M-form was an innovative response to these challenges. ${ }^{7}$ Although, imitation of the M-form was at first rather slow, by the 1960s the M-form appears to have become the dominant organizational form among large diversified firms. Chandler's framework has been very successful in explaining the evolution of the large manufacturing and transports firms, and it also explains why large firms emerged in certain industries rather than in others. Williamson's comment on the M-form is based partly upon Chandler's (1962) work.

The M-form, as described by Williamson (1975:132154), exhibits (distinctive) features not found in the U-form. The divisions are organized mainly along product, brand or geographic lines. Each division deals with a conceptually different business and is selfcontained with its own functional hierarchy, i.e., each division is divided along functional lines. The divisions are given a day-to-day operating decisions (Chandler 1962), while the corporate office is concerned with strategic decisions and can use incentives to favor operating behavior consistent with their objectives. A major difference with regard the U-form is that each division's contributions to profits are both directly observable and measurable. A consequence of these attributes is that there are a number of autonomous profit centers within the Mform, competing with each other for resources. Effective multidivisional structure involves the general office in the following set of activities (Williamson 1985:284): (1) the identification of separable economic activities within the firm, (2) according quasiautonomous standing to each, (3) monitoring the efficiency performance of each division, (4) awarding incentives, (5) allocating cash flow to high-yield uses, and (6) performing strategic planning (diversification, acquisition, divestiture).

Williamson (1985) argues that the reason for the emergence of the M-form is related to the failure in capital market which is unable to discipline firms not maximizing profits, either by denying them access to new capital fund, or by giving them a lower market valuation. Williamson contrasts these limitations of the external capital market with the advantages of the internal one. That is, within the M-form, since the headquarter has an informational advantage, the resource allocation may be more efficient than in the external market. According to Williamson (1981) the general office allocates resources between the competing divisions depending on their evaluation of relative yield. That is why Williamson views the $\mathrm{M}$ form as having a miniature (internal) capital market. As a consequence Williamson regards the M-form firm as capitalism's creative response to the limits of capital markets.

This logic became the dominant efficiency rationale for the existence of the diversified firm. What is of importance is that Williamson explains the M-form in his transaction cost framework: it economizes on the transaction costs of utilizing the capital market to discipline firms not maximizing profits.

Williamson's major conclusion is that the M-form can achieve a more nearly optimal resource allocation than the U-form: "the organization and operation of the large enterprise along lines of the $\mathrm{M}$-form favors goal pursuit and least-cost behavior more nearly associated with the neoclassical profit maximization hypothesis than does the U-form organizational alternative" (Williamson 1970:134). To put it differently, the Mform achieves greater efficiency than the U-form by reducing opportunism and information distortion, which postulates that firms with an M-form structure

\footnotetext{
${ }^{6}$ Two pioneers of adopting an M-form structure were GM in 1921 under the leadership of Alfred P. Sloan and DuPont Company under Pierre S. du Pont.

${ }^{7}$ Williamson (1985:279) himself writes that "the most significant organizational innovation of the twentieth century was the development in the 1920s of the multidivisional structure".
} 
would outperform firms operated with other organizational forms. ${ }^{8}$ This is Williamson's M-form hypothesis. ${ }^{9}$

\section{The U-form and the M-form beyond Williamson}

However, the superiority of the M-form argued by Williamson, is not above all criticisms. Sen (1993) proves that, if the control loss problem could be solved, the U-form would always be superior to the M-form. He also shows the reasons behind this: the principal has access to a greater amount of information under the U-form and if such availability is not associated with a noise problem, then the functional form is more efficient than the multidivisional one. Moreover, if the control loss problem could not be solved the growth of the U-form aggravates the control loss problem and as a consequence leads to the emergence of the M-form. ${ }^{10}$ But, once the control loss problem is solved by decentralizing production among divisions, the functional form reappears within each division, confirming that the U-form is the natural form of organization. ${ }^{11}$ In other words, the operating divisions may be characterized as scaled-down U-form firms (Hill 1985). A major conclusion of this is that neither the $\mathrm{M}$-form nor the $\mathrm{U}$-form is a priori superior over the other.

Another significant aspect not considered by Williamson is that whether the $\mathrm{U}$ and $\mathrm{M}$-form structures should simply be regarded as different internal organizational structures or the differences between them reside in other. In my view, the important thing is not that these two forms represent different firm organizational structures; rather, it is that the $\mathrm{M}$-form entails some market-like (high-powered) incentives as opposed to the U-form. Briefly, the Mform's divisions are encouraged to behave in a more entrepreneurial way unlike the U-form's departments. The important thing is that, as compared with the Mform, the U-form is a more centralized structure (Sen
1993). That is, the distinction between $\mathrm{U}$ and $\mathrm{M}$-forms can be paralleled with that between market and hierarchy (firm): the M-form firm must be seen as decentralized compared to the U-form like the market is decentralized compared to the firm. As a consequence, the $\mathrm{U}$ and the $\mathrm{M}$-form use different centralization, integration and control devices and incentive systems.

A third important thing is that, as a number of empirical studies (e.g. Hoskisson 1987) suggest, the M-form structures do not constitute a homogeneous set, instead, embrace a wide range of forms. ${ }^{12}$ Considerable variation are detected concerning the size of the corporate office, the use of internal governance mechanisms, such as operating budgets, strategic plans and performance reports, and the vertical delegation of strategic tasks. Hoskisson et al. (1993) identify two variations within the $\mathrm{M}$-form: the cooperative and the competitive (pure M-form) organizations. These two variants of the M-form are best suited for different firms trying to realize benefits from different strategies. An M-form structure with cooperation between divisions is associated with the realization of economic benefits from vertical integration and related diversification. In this form some centralization is necessary to achieve a coordination, which encourages the corporate office to retain some control over functions common to the divisions.

As far as the other variant of the M-form is concerned, as Williamson has also argued, benefits from an internal capital market require an $\mathrm{M}$-form structure within which competition between divisions is emphasized. This implies certain features (Hoskisson et al. 1993:283) that produce competition among divisions for capital: (1) each division must have autonomy with regard to operating decisions, (2) the relationship between the general office and divisions should be an arms-length one, (3) the general office should set rate of return targets, (4) incentive systems for divisional managers should be linked to divisional returns, (5) cash flows should be allocated between

\footnotetext{
${ }^{8}$ It has to be noted that Williamson makes a distinction not only between the $\mathrm{U}$ and the M-forms, but also between pure M-form and the "corrupted" M-form in which top managers are involved in divisional operating decisions. He also talks about the H-form (holding companies) within which no internal capital market exists. Williamson predicts that the M-form outperform not only the U-form, but also the "corrupted" M-form and the H-form.

${ }^{9}$ The M-form hypothesis inspired, and continues to inspire numerous empirical studies, for an overview see: Hoskisson et al. (1993). However, some of these offer only a weak support for the M-form hypothesis, while others find no evidence of superior M-form performance.

${ }^{10}$ The U-form suffers from control loss problem to a greater extent than the M-Form (Williamson 1970). These problems flow from the nonseparability of activities: any functional department has to carry out its activity with respect to all the products of the firm.

${ }^{11}$ As Williamson (1975:133) writes "specialization by function ... is the 'natural' way by which to organize multifunctional activities".

${ }^{12}$ Note that there are variants, too, within the U-form. Some U-form firms have become diversified in slight degree and incidental parts are given semi-autonomous standing.
} 
divisions by the general office to high yield uses on competitive basis.

That is, realization of economies stemming from specific assets, scope and realization of internal capital market, which are associated respectively with vertical integration, related and unrelated diversification imposes organizational requirement on the firm. Note that variants within the M-form should be paralleled to those within a firm.

To summarize it, I have added three important aspects to the Williamsonian picture on the M-form: (1) neither the $\mathrm{M}$-form nor the $\mathrm{U}$-form are a priori superior over the other, (2) the M-form uses some high-powered incentives and less administrative controls compared to the U-form, (3) there are variants within the M-form as well. These assertions have implications for the rest of the paper.

\section{New variant of the firm: a market-like form}

Let me summarize the defining characteristics of the M-form (Chandler 1990, Rajan - Zingales 2000). It is (1) large enough to exploit potential economies of scale and scope in production, (2) physical capitalintensive, (3) integrated both forward and backward, (4) oligopolistic, (5) run by professional managers which leads to the agency problem between owners and managers.

Compared to this, firms are significantly transforming in the New Economy: there is an ongoing process in which market-like elements such as high-powered incentives and entrepreneurship penetrate the firm (Zenger - Hesterley 1997). In fact, what is happening is a disaggregation process, i.e., the transformation of Chandlerian vertically integrated corporations. What are the major attributes of the organizational "outcome" of this process?

The transformed organization ${ }^{13}$ encompasses a flatter hierarchy, a decentralized decision structure, which is built on self-organizing autonomous teams. The corporate centre takes advantage of the teams' entrepreneurship and responsibility; consequently the monitoring and the authority are significantly cons- trained compared to the $\mathrm{M}$-form firm. Teams are organized cross-functionally around a well-defined task, observable output or project (Zenger 2002). Rather than measuring the individuals' performance, these forms measure the output of the teams and reward them. Inter-teams relationships should be regarded as quasi-contractual, employees as quasiowners of the assets they use (Helper et al. 2000). Managers exercise guidance, manage conflict situations and enable communication among the teams rather than directly commanding and controlling them (Child - McGrath 2001). Many argue that these forms try to bring the market inside the firm.

Perhaps the main differences compared to the M-form corporation are (1) the increased importance of human capital relative to inanimate assets, and (2) the breakup of the vertical integration. As the importance of human capital grows, power moves away from the top and is much more widely dispersed through the firm. Another major feature is the changing character of specialization (Rajan - Zingales 2000): while the employees of the Chandlerian firm are technically specialized to the firm, those of the market-like form have firm-specific ${ }^{14}$ capabilities.

To sum it up, three kinds of change take place regarding the nature of the firm (Foss 2001). First, authority relations vanish, or at least change radically in character ${ }^{15}$. Second, boundaries of the firm are becoming vague; the ownership-based ${ }^{16}$ understanding of firms' boundaries is becoming rather irrelevant (Helper et al. 2000). Third, coordinating mechanisms characteristic of the market (e.g. entrepreneurship, high-powered incentives, reward on performance, etc.) are intensively used within the firm. Table 2 explores the main differences between the $\mathrm{M}$-form and the market-like form.

As suggested in the literature (among others Foss 2002), there exist a wide array of market-like forms depending on which of the above-mentioned features and to what extent they are present in a given form. Some of them radically break with the traditional hierarchy (such as the cellular form); while others introduce only some new mechanisms (such as reward by performance, or empowerment) and retain the traditional form.

\footnotetext{
${ }^{13}$ There is a multitude of labels as regards these forms of organization, for instance a modular organization (Sanchez - Mahoney 1996), a cellular firm (Miles et al. 1997), a non standard firm (Helper et al. 2000), a federation (Day - Wendler 1998), and so on. The terminology is rather ambiguous: different labels are used for describing the same or similar things.

${ }^{14}$ Firm-specific specialization is a specialization to the idiosyncratic needs of the firm.

${ }^{15}$ Control over valuable human capital would seem to be a greater source of power than control over physical assets since almost all rights over it are residual, i.e., not allocable through contract (Rajan - Zingales 2000).

${ }^{16}$ The theory of the property rights (Hart 1995) defines the boundaries of the firm on the basis of the assets owned by the firm.
} 
Table 2. Comparison of the M-form with the Market-like Form

\begin{tabular}{|c|c|c|}
\hline Criterion & M-form & Market-like Form \\
\hline Structure & 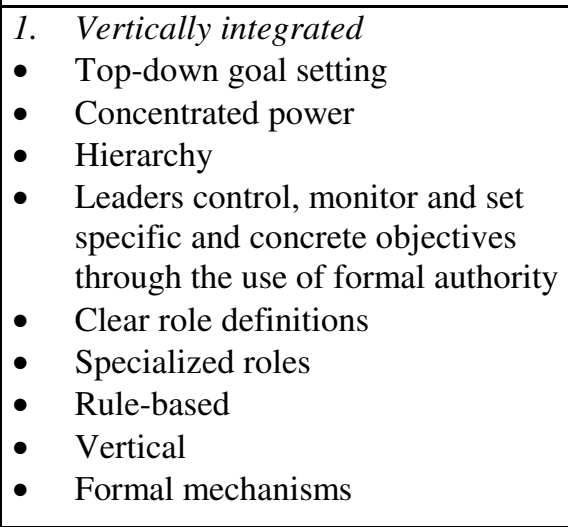 & $\begin{array}{l}\text { 2. Disintegrated } \\
\text { 6. Decentralized goal setting } \\
\text { 7. Distributed power } \\
\text { 8. Teams and work groups } \\
\text { 9. Leaders provide guidance, } \\
\text { manage conflict and provide } \\
\text { general guidance } \\
\text { 10. Fuzzy role definitions } \\
\text { 11. General roles } \\
\text { 12. Relationship-based } \\
\text { 13. Horizontal } \\
\text { 14. Informal mechanisms }\end{array}$ \\
\hline Critical asset & 3. Inanimate (physical) capital & 4. $\quad$ Human capital \\
\hline Specialization & 5. $\quad$ Technical & 6. $\quad$ Firm-specific \\
\hline Source of power & 7. $\quad$ Control over physical assets & 8. Individual's valuable resource \\
\hline Economies & 9. Economies of scale and scope & $\begin{array}{l}\text { 10. Economies of scope } \\
\text { 11. Modularity }\end{array}$ \\
\hline Demand & 12. Undifferentiated products & 13. Distinctive and individualized \\
\hline Firm boundary & $\begin{array}{l}\text { 14. Boundaries clearly specified and } \\
\text { durable }\end{array}$ & $\begin{array}{l}\text { 15. Boundaries permeable and fuzzy } \\
\text { 16. Quasi-contractual inter-teams } \\
\text { relationships }\end{array}$ \\
\hline Reward & 17. Based on individual performance & 18. Based on team performance \\
\hline Sector & $\begin{array}{l}\text { 19. Traditional (physical capital } \\
\text { intensive) }\end{array}$ & 20. Knowledge-intensive \\
\hline $\begin{array}{l}\text { Transaction costs of using } \\
\text { the firm (agency, shirking, } \\
\text { contract enforcement and } \\
\text { coordination costs) }\end{array}$ & 21. Low & 22. High \\
\hline
\end{tabular}

My argument is that the above-described form must be considered a new variant of a firm, whose understanding should be in line with that of the Mform put forth by Chandler (1977). This flows from the fact that the firm is subject to a slow evolution process which produces new variants between times. As a consequence, what is the fundamental cause behind this evolution is, at the same time that of the emergence of both the M-form and the market-like form.

Of course, numerous factors contributed to the emergence of the M-form firm. Of them, Williamson explores transaction $\operatorname{costs}^{17}$, while the strategic management literature does the issue of strategic contingencies, and other authors point out other factors. Chandler (1990) himself paid special attention to the role of the lowering of transportation and communication costs, and as a result to the fact that markets became thicker. Langlois (2003a) is in accordance with this view: he argues that, while the above-mentioned factors all affect organizational structure, none of them alone can drive organizational change. What drive organizational changes are factors affecting production costs and production technology.

What are the forces that are changing the nature of the firm in the New Economy? I think the same as in case of the M-form apply, but new ones also appear. These are the following (Rajan - Zingales 2000): (1) Drop in the cost of information collection which leads to more intense competition. (2) Reduction in the barriers to trade making markets bigger and supporting more competition and less need of vertical integration. (3) Reduction in the role of government (end of regulated monopolies). (4) Development of financial markets that facilitates new entry. (5) Rapid and dramatic change in information and communication technologies.

I follow Langlois' (2003a) argument according to

\footnotetext{
${ }^{17}$ However, in fact, neither the U-form collapse nor the subsequent search for new forms (rather than selection from existing form) is explained by Williamson (Kay 1992:328).
} 
which all of them play a role in the emergence of a market-like form, but the fifth factor is the determining. Briefly, it is technology that is the driving force behind firm evolution - while admitting that there have been a number of contributing factors -, however, firm organization should go hand-in-hand with this. A useful concept to explore this relationship is that of the social technology.

Nelson (2002) proposes to distinguish between physical and social technologies. Physical technology refers to production technology used in a society. "Social technologies are defined by and define the rules of the game" (ibid. pp. 22). This is a broad concept encompassing both ways of organizing activities within organizations, and ways of organizing transactions across organizational borders, which involves patterned human interactions. This means that both variants of the firm (U, M, and market-like form) and governance structures (firm, market, and hybrid form) have to be seen as social technologies. They provide a low transaction cost ways of getting something done. Nelson (2002) also argues that social technologies are to seen not so much as constraints on behavior, but rather as defining the effective way to do something.

No doubt that physical technology must be in accordance with social technology. The important thing is that physical and social technologies change at different rate: while technological change is rather continuous, social technology entails many inertial elements making changes in social technology discontinuous. To put it differently, the changes in social technology lag behind the changes in physical technology, but once the tension between the new physical technology and the old social technology is large enough not to support their co-working, social technology must also change. This implies that social technology has certain flexibility (Nelson - Sampat 2001) to fit in with various physical technologies.

What is the implication of this as regards the evolution of firm forms? During the mid $19^{\text {th }}$ century, due to the technological innovations - including the telegraph, the development of continuous process machinery, the refinement of interchangeable parts manufacture (Chandler 1977) - a new production technology of the mass production became dominant. However, the most important new technology were railroads which were not only "the first modern business enterprises" (Chandler 1977:120), but also to a significant extent new technology for manufacturing firms. Railroad contributed to a dramatic decrease in transportation costs, and as a result it expanded the market in way never seen before. This new physical technology required new social technology, i.e., new modes of organizing businesses in order to take advantage of the new opportunities of scale and scope. At that time the new social technology was the M-form structure which, as Chandler (1962) argued, arose and succeeded because it was more efficient than its predecessors. ${ }^{18}$ It is clear that Chandler's story is a story of coevolution of technology and business organizations (Nelson 1995:64). He also argued that a variety of technological development occurred during the mid and late $19^{\text {th }}$ century which opened up the possibility for firms to operate at large scale with relatively wide range of products.

What is happening in the New Economy? Information and communication technology change at a rate never seen before. The new technology diffuses rapidly in the economy. On the one hand, new industries are developing, such as internet technology, information industry, biotechnology, and, on the other hand, traditional industries such as machinery, textile or printing are changing in character. Moreover, this new information technology provokes fundamental changes in production technology which could not work well with the M-form structure. Just as the implementation of the new physical technology may require new machinery, new materials and new inputs, as well as new social technologies. These new social technologies, among them the market-like structure emerge largely because they are needed and useful.

One of the most significant features of New Economy's technology is that it favors modular products. As argued by Sanchez and Mahoney (1996) product modularity requires modular organization, i.e., firms with project-oriented teams behaving entrepreneurially, which are rewarded on their performance. In other words, modular products need modular organization that may be characterized by less need for management (Langlois 2002). As Langlois (2002) argues a market is a most modular organization, while „firms arise as islands of non-modularity in a sea of modularity" (Langlois 2002:34). A significant thing is that the market-like form infuses modularity into firms that are basically non-modular structures. As being disintegrated, the market-like form can benefit from the external capabilities of the entire economy

18 According to Williamson (1985:296) the evolution of the M-form is regarded as an evolutionary process operating according to natural selection criteria that is economic (cost) efficiency. 
(Langois 2003a). Accordingly, the contemporary tendency is for the transformation of the tightly integrated systems (firms) into loosely coupled disaggregated structures. However, technology also induces shifts in customer's demand: customized products $^{19}$ are preferred, which also increases modularity both as regards products and firm organization.

To sum it up, changes in physical technology dictate changes in social technologies. Variants of the firm are to be considered particular social technologies which emerge to a considerable extent as responses to significant changes in physical technology.

Up to now, I have, in fact, discussed only one question as regards the issue of the evolution of a firm: the cause(s) of the emergence of a new variant. My argument is that we have to add three more questions to this in order to better understand the whole issue. These concern the essential differences between variants, the distinctive feature of a firm, and the why of the coexistence of variants. I will provide answers to these below.

\section{What makes the firm a firm?}

Recall what is meant by variants of a firm. As said above, they are representatives of the firm as governance structure in Williamsonian sense, which exhibit to a certain extent different characteristics while retaining the same distinctive one which guarantees that they are of the same nature.

This being said, we have to investigate the question of what is common in all variants of the firm. As shown above, there are significant differences between the U-form, M-form and the market-like form. But what makes them a firm? An understanding of the essence of a firm requires finding out the unique attributes of a firm, i.e., those that exclusively characterize it.

In my view, a distinction between coordination mechanisms and arenas of coordination may be useful in the understanding. Why is this so important? When considering the market-like form many authors argue that the market penetrates the firm. However, this is an inaccurate terminology, as the market cannot penetrate the firm because it differs in essence from it. To put it more precisely, those coordination mechanisms penetrate the firm that are much more characteristic of the market than of the firm.

I have argued elsewhere (Kapis 2002) that the firm like the market is to be considered an arena of coordination rather than a mechanism of coordination. The firm is a complex of coordinating devices (Ménard 1994), i.e., it encompasses diverse coordinating mechanisms. Variations of the firm differ from one another in the proportions in which different coordinating mechanisms ${ }^{20}$ are combined.

When having analyzed the M-form, I have argued that the $\mathrm{M}$-form uses some market-like elements: division managers are given legitimacy and power, they are rewarded on division profits, some autonomy is given to divisions as regards operating decisions, there is a competition for financial resources between divisions, etc. This suggests that the M-form uses less command and administrative tools than the U-form. That is, the M-form uses more coordinating mechanisms characteristic of the market as compared to the Uform. The same apply for variants within the M-form: as said above, market-like elements (high-powered incentives) are present to a greater extent in the competitive M-form compared to the cooperative one.

The important thing is that the penetration of the market-like elements is much more intensive in the market-like forms than in the M-form because the market-like form represents a radically different structural philosophy. It is based on an assumption that the firm needs to be managed on a principle of proliferation of small independent entrepreneurial units, rather than on divisions. This philosophy implies a significantly different allocation of assets and resources within a firm. Here resources are decentralized to teams which operate in interdependence with one other. In these firms planning, coordination and control systems have been radically redesigned and simplified. Clearly, the tendency itself is the same: moving from the U-form towards the M-form, and then towards the market-like form the mix of the coordinating mechanisms shifts towards encompassing more and more high-powered incentives. ${ }^{21}$

\footnotetext{
An overview of the question of mass customization is in Szabó (2000).

Coordinating mechanisms are such as authority, command, price system, trust, reciprocity, etc.

21 Following Alston and Gillespie (1989) we can distinguish between transaction costs of using the market and those of using the firm. When more and more high-powered incentives are used inside the firm, the transaction costs of using the firm, i.e., agency, coordination, and shirking and contract enforcement costs become larger. This means that these transaction costs are much higher in the market-like forms than in the M-form, and the transaction costs of using the market evolve in the opposite way. Accordingly, when a new variant of the firm emerges, the boundary between the two types of transaction costs shifts.
} 
Having said that, the question of what is common in all variants should be explored. It is now clear that coordinating mechanisms predominating in markets are present to a greater extent in a market-like form. This means that there is a relatively large limit within which high-powered incentives may occur within a firm. But what is a distinguishing mark of a firm? As shown elsewhere (Kapis 2003), authority is to be regarded as a predominating coordinating device inside all variants of the firm. ${ }^{22}$ That is, the distinguishing feature of the firm is the predominance of authority among coordinating devices used within the firm. Thus, firm exists in numerous variations, namely the U-form, the M-form and the market-like form, which differ from one another in the proportions in which the different coordinating mechanisms are combined.

\section{Why the coexistence?}

The fundamental attribute of what makes the firm a firm is preserved in all variants of the firm, however, significant differences also occur. All variants must be regarded as efficient solutions to the economic problem of their own age. As a result none of them has an a priori supremacy over the others. Both the multidivisional and the market-like form have brought significant added value with regard to the previous forms, and they must be seen as suitable responses to the requirements of their ages. This being said, how the coexistence of numerous variants may be explained?

We must agree with the claim of Miles et al. (1997) according to which cellular forms (market-like forms) are advantageous only in cases when products require rapid innovation. For those firms that produce standard products the hierarchical form continues to be more advantageous. That is, the market-like forms are best suited to the requirements of the New Economy, and they are basically present in knowledge-intensive industries such as the biotechnology and semiconductor industries. However, U or M-forms continue to prosper in the traditional physical capitalintensive industries. Nowadays the decentralized structures have become predominant forms only to the extent that knowledge-intensive industries - where they have a comparative advantage - have gained ground in the economy. Why?
The evolution of a firm does not take place in a way that with the emergence of a new variant the older ones would have to disappear. On the contrary, the new variant always retains the older ones, that is, with the birth of the M-form the U-form has not disappeared. Similarly, after the emergence of the market-like form the $\mathrm{U}$ and $\mathrm{M}$-forms continue to prosper in some industries. Any new variant has always emerged as a result of an efficient answer to some significant change in physical technology. Since those circumstances in which the new variant has a comparative advantage never predominate in the whole economy, the older forms continue to be advantageous for the firms that operate under the old technology. This is the very reason why various variants of the firm coexist. This reflects the fact that each variant of the firm has a comparative advantage in different physical technological regime. The U-form is still the appropriate structure for most small- and middle-sized firm.

It would be erroneous to overestimate the importance of the market-like forms; their emergence and proliferation must rather be regarded as results of the same process in which the multidivisional form also emerged, i.e., the evolution of a firm. Consequently, the tendency itself is a not a new one: the changing character of physical technology requires new social technologies.

\section{Conclusions}

My starting point in this paper was a shortcoming of the dominant transaction cost theory of the firm, i.e., the explanation of the evolution of a firm. So in this paper I was concerned with the issue of variants within a firm, the causes of their emergences and their coexistence. A short by-pass towards the question of a distinctive feature of a firm was inevitable.

Variants of the firm (the $\mathrm{U}$, the $\mathrm{M}$ and the market-like form) should be conceived as comprising low and high-powered incentives, but, to varying degree. A market-like form exhibit the highest level of highpowered incentives, the U-form encompasses almost none of them, and the M-form is in-between.

Significant shifts in physical technology were thought to be a major force driving the evolution process of a firm which is characterized by the emergence of new variants, i.e., new social technologies. Social technologies must follow physical technologies: each

\footnotetext{
${ }^{22}$ It is not the use of authority itself that distinguishes a firm from markets and hybrids, since markets and, especially, hybrids are also infused with a lower level of authority. Many scholars argue and provide evidence for the fact that a kind of authority is observable in hybrids. See: Ménard (2004).
} 
variant of the firm is particularly suitable for different production technology: standard products needs the Uform, mass production favors the M-form while modular products the market-like structures.

\section{References}

Alston, L. J. - Gillespie, W. (1989) Resource Coordination and Transaction Costs: A Framework for Analyzing the Firm/Market Boundary. Journal of Economic Behavior and Organization 11. 2: 191-212.

Barnard, C. (1938) The Functions of the Executive. Cambridge MA: Harvard University Press. 1962.

Chandler, A. D. (1962) Strategy and Structure. Cambridge: MIT Press.

Chandler, A. D. (1977) The Visible Hand: the Managerial Revolution in American Business. Cambridge, MA.: Harvard University Press.

Chandler, A. D. (1990) Scale and Scope: The Dynamics of Industrial Capitalism. Cambridge: MIT Press.

Child, J. - McGrath, R. (2001) Organizations Unfettered: Organizational Forms in an Information Intensive Economy. Academy of Management Journal, 44, p. 1135-1148.

Coase, R. H. (1937) The Nature of the Firm, Economica 4. 16: 386-405.

Day, J. - Wendler, J. (1998) The New Economics of Organizations. McKinsey Quarterly: 4-18.

Foss, N. J. (2001) Misesian Ownership and Coasian Authority in Hayekian Settings: The Case of the Knowledge Economy. Quarterly Journal of Austrian Economics 4. 4: 3-24.

Foss, N. J. (2002) 'Coase vs Hayek': Authority and Firm Boundaries in the Knowledge Economy. International Journal of the Economics of Business 9. 1:9-36.

Hart, O. (1995) Firms, Contracts, and Financial Structure, Oxford University Press, New York, Oxford.

Hayek, F. A. (1945) The Use of Knowledge in Society. In: Individualism and Economic Order. London: Routledge and Kegan Paul. 1976. pp. 71-99.

Helper, S. - MacDuffie, J. P. - Sabel, C. (2000) Pragmatic Collaborations: Advancing Knowledge While Controlling Opportunism. Industrial and Corporate Change 9. 3:443-487.

Hill, C. W. L. (1985) Oliver Williamson and the M-form Firm: A Critical Review. Journal of Economic Issues 19. Sep:731-751.

Hoskisson, R. E. (1987) Multidivisional Structure and Performance: The Contingency of Diversification Strategy. Academy of Management Journal 30:625-644.

Hoskisson, R. E. - Hill, C. W. L. - Kim, H. (1993) The Multidivisional Structure: Organizational Fossil or Source of Value? Journal of Management 19. 2:169-298.

Kapás, J. (2002) Arenas of Exchanges. Paper for the
Conference on Evolution of Institutions and the Knowledge Economy, October 4-5, 2002, Debrecen, Hungary.

Kapás, J. (2003) Mutáns vállalatok? A belső hibridekről (Mutants Firms? On the Internal Hybrids). Közgazdasági Szemle (Economic Review) L. 4: 335-349.

Kay, N. M. (1992) Markets, False Hierarchies and the Evolution of the Modern Corporation. Journal of Economic Behavior and Organization 17:315-333.

Langlois, R. N. (2002) Modularity in Technology and Organization. Journal of Economic Behavior and Organization 49:19-37.

Langlois, R. N. (2003a) The Vanishing Hand: the Changing Dynamics of Industrial Capitalism. Industrial and Corporate Change 12. 2:351-385.

Langlois, R. N. (2003b) Chandler in a Larger Frame: Markets, Transaction Costs and Organizational Form in History. Working Paper, University of Connecticut.

Ménard, C. (1994) Organizations as Coordinating Devices. Metroeconomica 45. 3:224-247.

Ménard, C. (2004) The Economics of Hybrid Organizations. Journal of Institutional and Theoretical Economics 160:1-32.

Miles, R. E. - Snow, C. C. - Mathews, J. A. - Miles, G. Coleman, H. J. (1997) Organizing in the Knowledge Age: Anticipating the Cellular Form. Academy of Management Executive 11. 4:7-20.

Nelson, R. R. (1995) Recent Evolutionary Theorizing About Economic Change. Journal of Economic Literature 33:48-90.

Nelson, R. R. (2002) Bringing Institutions into Evolutionary Growth Theory. Journal of Evolutionary Economics 12:17-28.

Nelson, R. R. - Sampat, B. H. (2001) Making Sense of Institutions as Factor Shaping Economic Performace. Journal of Economic Behavior and Organization 44:3154.

Rajan, R. - Zingales, L. (2000) The Governance of the New Enterprise. Megjelent: Vives, X. (ed.): Corporate Governance. Cambridge: Cambridge University Press. p. 201-227.

Sanchez, R. - Mahoney, J. T. (1996) Modularity, Flexibility, and Knowledge Management in Product and Organizational Design. Strategic Management Journal 17: 63-76.

Sen, A. (1993) The Structure of Firms. Journal of Economic Behavior and Organization 20:119-130.

Szabó, K. (2000) A személyes tömegtermelés (Mass Customization). Külgazdaság XLIV. 9:35-49.

Williamson, O. E. (1964) The Economics of Discretionary Behavior: Managerial Objectives in a Theory of the Firm. Englewood Cliffs, N.J.: Prentice Hall.

Williamson, O. E. (1970) Corporate Control and Business Behavior. Englewood Cliffs, N.J.: Prentice Hall. 
Williamson, O. E. (1975) Markets and Hierarchies: Analysis and Antitrust Implications. New York: The Free Press.

Williamson, O. E. (1981) The Modern Corporation: Origin, Evolution, Attributes. Journal of Economic Literature 19:1537-1568.

Williamson, O. E. (1985) The Economic Institutions of Capitalism. New York: Free Press.

Williamson, O. E. (1988) The Logic of Economic Organization. Journal of Law, Economics and Organization 41. 1:65-94.

Williamson, O. E. (1991) Comparative Economic
Organization: The Analysis of Discrete Structural Alternatives. Administrative Science Quarterly 36:269296.

Zenger, T. R. - Hesterley, W. S. (1997) The Disaggregation of Corporations: Selective Intervention, High-Powered Incentives, and Molecular Units. Organization Science 8:209-222.

Zenger, T. R. (2002) Crafting Internal Hybrids: Complementarities, Common Change Initiatives, and the Team-Based Organization. International Journal of the Economics of Business 9. 1:79-95. 